\title{
New method for selection of hydrogen peroxide adapted bifidobacteria cells using continuous culture and immobilized cell technology
}

\author{
Valeria Mozzetti ${ }^{1}$, Franck Grattepanche ${ }^{\text {, Déborah Moine }}{ }^{2}$, Bernard Berger ${ }^{2}$, Enea Rezzonico ${ }^{2}$, Leo Meile ${ }^{1}$, \\ Fabrizio Arigoni ${ }^{2}$, Christophe Lacroix ${ }^{1 *}$
}

\begin{abstract}
Background: Oxidative stress can severely compromise viability of bifidobacteria. Exposure of Bifidobacterium cells to oxygen causes accumulation of reactive oxygen species, mainly hydrogen peroxide, leading to cell death. In this study, we tested the suitability of continuous culture under increasing selective pressure combined with immobilized cell technology for the selection of hydrogen peroxide adapted Bifidobacterium cells. Cells of B. longum NCC2705 were immobilized in gellan-xanthan gum gel beads and used to continuously ferment MRS medium containing increasing concentration of $\mathrm{H}_{2} \mathrm{O}_{2}$ from 0 to $130 \mathrm{ppm}$.

Results: At the beginning of the culture, high cell density of $10^{13} \mathrm{CFU}$ per litre of reactor was tested. The continuous culture gradually adapted to increasing $\mathrm{H}_{2} \mathrm{O}_{2}$ concentrations. However, after increasing the $\mathrm{H}_{2} \mathrm{O}_{2}$ concentration to $130 \mathrm{ppm}$ the $\mathrm{OD}$ of the culture decreased to 0 . Full wash out was prevented by the immobilization of the cells in gel matrix. Hence after stopping the stress, it was possible to re-grow the cells that survived the highest lethal dose of $\mathrm{H}_{2} \mathrm{O}_{2}$ and to select two adapted colonies (HPR1 and HPR2) after plating of the culture effluent. In contrast to HPR1, HPR2 showed stable characteristics over at least 70 generations and exhibited also higher tolerance to $\mathrm{O}_{2}$ than non adapted wild type cells. Preliminary characterization of HPR2 was carried out by global genome expression profile analysis. Two genes coding for a protein with unknown function and possessing trans-membrane domains and an ABC-type transporter protein were overexpressed in HPR2 cells compared to wild type cells.
\end{abstract}

Conclusions: Our study showed that continuous culture with cell immobilization is a valid approach for selecting cells adapted to hydrogen peroxide. Elucidation of $\mathrm{H}_{2} \mathrm{O}_{2}$ adaptation mechanisms in HPR2 could be helpful to develop oxygen resistant bifidobacteria.

\section{Background}

According to FAO/WHO (2002) [1], probiotics are defined as "live microorganisms which when administered in adequate amounts confer a health benefit on the host". One of the crucial points in the production and distribution of probiotic foods is hence to deliver enough live probiotic cells to the consumers. The minimum daily intake of probiotics to obtain a beneficial effect is still under debate. However, a concentration of $10^{6}$ live cells of probiotic bacteria per gram of product

\footnotetext{
* Correspondence: christophe.lacroix@ilw.agrl.ethz.ch

'Laboratory of Food Biotechnology, Institute of Food Science and Nutrition, Schmelzbergstrasse 7, ETH-Zurich, 8092 Zürich, Switzerland
}

at the time of consumption is generally accepted and selected to provide bacterial concentrations that are attainable and cost-effective for probiotic food products [2]. During production and storage of food, microorganisms experience a wide range of stresses, including oxidative stress, which can severely compromise cell viability of sensitive strains as well as their incorporation into food products.

Bacterial strains belonging to Bifidobacterium and Lactobacillus genera are the most widely used microorganisms in probiotic food products and supplements [3]. Bifidobacteria are obligate anaerobes. However, some species can tolerate oxygen, such as B. psychroaerophilum, B. indicum and B. asteroides, the latter two

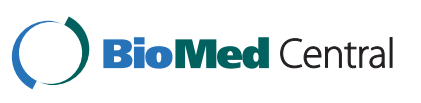


possessing catalase $[4,5]$. Exposure to oxygen induces accumulation of reactive oxygen species, mainly hydrogen peroxide, which cause oxidative damage to vital cellular components, resulting in cell death of sensitive cells $[6,7]$.

Although oxygen tolerant bifidobacteria can be isolated from the environment [8], these isolates do not necessarily exhibit relevant probiotic characteristics. Mutagenic agents have also been applied to obtain oxygen resistant bifidobacteria [9]. However, random mutations affecting the probiotic characteristics of the strain may occur. Another method to isolate stress resistant bacterial strains consists in culturing cells in presence of a selective agent. Plating and cultivation in batch cultures with varying concentration of a selective agent are fairly simple procedures, but the number of generations over which selection can occur is limited. Therefore repeated cycles of subculturing may be required. In contrast to batch, continuous culture can be performed over an unlimited number of generations under strictly controlled conditions. Moreover, it can ensure continuous presence of unstable selective agents, such as hydrogen peroxide that can be broken up into nascent oxygen and water in contact with organic matter of rich media like MRS broth [10]. However, the use of continuous culture combined with selective pressure is limited because the resistance level of cells can greatly vary with fermentation time. In addition, an over-dosage of the selective agent leads generally to a wash-out of cells from the reactor. This major drawback of continuous cultures can be prevented using immobilized cell technology, which allows retaining cell in reactor even if dilution rate exceed growth rate of the culture [2,11].

The aim of this study was to test the application of continuous culture with immobilized cells for selecting hydrogen peroxide adapted populations of $B$. longum NCC2705.

\section{Methods}

\section{Bacterial strain}

B. longum NCC2705 was obtained from the Nestlé Culture Collection (Lausanne, Switzerland) and cultivated in MRS [12] medium (Biolife, Milano, Italy). Two successive pre-cultures, inoculated at $1 \%$ from a frozen stock at $-80^{\circ} \mathrm{C}$ in MRS with $10 \%$ glycerol (SigmaAldrich, Buchs, Switzerland), were performed for $16 \mathrm{~h}$ under anaerobic (AnaeroGen, Oxoid, Basingstoke, United Kingdom) conditions at $37^{\circ} \mathrm{C}$ before use.

\section{Cell immobilization}

Cell immobilization was based on a two-phase dispersion process as previously described [13]. A mixed gel of 2.5\% $(\mathrm{w} / \mathrm{v})$ gelrite gellan gum and $0.25 \%(\mathrm{w} / \mathrm{v})$ xanthan gum (both Sigma-Aldrich) was inoculated at $2 \%(\mathrm{v} / \mathrm{v})$ with a pre-culture of $B$. longum NCC2705, containing ca. $10^{9}$ $\mathrm{CFU} \mathrm{ml}{ }^{-1}$. Beads with diameters in the range of 1.0-2.0 $\mathrm{mm}$ were selected by wet sieving and used for fermentation. The entire process was completed within $1 \mathrm{~h}$.

\section{Continuous culture}

A volume of $70 \mathrm{ml}$ of inoculated gel beads was transferred into a 1-1 stirred tank reactor (Multifors, Infors$\mathrm{HT}$, Bottmingen, Switzerland) containing $630 \mathrm{ml}$ MRS. The reactor was stirred at $100 \mathrm{rpm}$ by an inclined blade impeller. Nitrogen was aseptically injected into the headspace of the reactor to maintain anaerobic conditions. Temperature was set at $37^{\circ} \mathrm{C}$ and $\mathrm{pH}$ was controlled and maintained at 6.0 by adding $5 \mathrm{M} \mathrm{NaOH}$. Culture was started in batch mode for the first $24 \mathrm{~h}$, followed by $24 \mathrm{~h}$ in continuous mode with feeding of MRS at $2.6 \mathrm{ml} \mathrm{min}{ }^{-1}$, using a peristaltic pump (Infors-HT), to allow colonization of gel beads. During this colonization step, immobilized population increased from $10^{7}$ to $10^{11}$ CFU g ${ }^{-1}$ of gel beads. Afterwards, feeding of $\mathrm{H}_{2} \mathrm{O}_{2}$ solutions was started, using a calibrated peristaltic pump (Infors-HT), and the culture was carried out in continuous mode for 23 days. Inflow rate of MRS, initially set

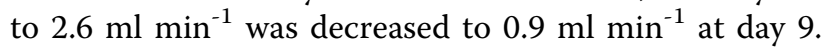
$\mathrm{H}_{2} \mathrm{O}_{2}$ was continuously added to the reactor at a flow rate 10 fold smaller than that of the MRS and using concentrated solutions ranging from 50 to $1,300 \mathrm{ppm}$ depending on the applied $\mathrm{H}_{2} \mathrm{O}_{2}$ level. $\mathrm{H}_{2} \mathrm{O}_{2}$ solutions were prepared using $30 \% \mathrm{H}_{2} \mathrm{O}_{2}$ (VWR, Dietikon, Switzerland) in sterile water. $\mathrm{H}_{2} \mathrm{O}_{2}$ solution was kept on ice, protected from light and replaced daily, to avoid $\mathrm{H}_{2} \mathrm{O}_{2}$ breakdown during the experiment. Effluent samples were collected from the reactor at different time intervals for optical density $(600 \mathrm{~nm})$ measurements using sterile MRS medium as reference, and cell enumeration using plate counts. Aliquots of $2 \mathrm{ml}$ effluent samples were centrifuged $(6,000 \mathrm{~g}$ for $2 \mathrm{~min})$ and pellets suspended in equal volume of fresh MRS containing $10 \%$ glycerol and stored at $-80^{\circ} \mathrm{C}$ for further analyses. Gel bead samples of $1 \mathrm{~g}$ were placed into $1 \mathrm{ml}$ of MRS with $10 \%$ glycerol and stored at $-80^{\circ} \mathrm{C}$ until analysis.

\section{Viable cell enumeration in culture effluent and gel beads} Samples from fermented effluent were serially diluted in phosphate buffered saline (pH 7.7) supplemented with $0.05 \%$ L-cysteine hydrochloride monohydrate (SigmaAldrich) (C-PBS). Appropriate dilutions were plated in duplicate on MRS agar (DIFCO, Becton Dickinson AG, Allschwil, Switzerland) and incubated anaerobically at $37^{\circ} \mathrm{C}$ for $48 \mathrm{~h}$. The immobilized cell population was also monitored by plate counts after adding ca. $0.5 \mathrm{~g}$ gel beads to $20 \mathrm{ml}$ 1\% EDTA (Sigma-Aldrich) and treatment in a stomacher (Seward, Norfolk, UK) for $3 \mathrm{~min}$ for bead dissolution before dilution in C-PBS and plating. 


\section{$\mathrm{H}_{2} \mathrm{O}_{2}$ resistance level of cells from culture effluent}

Resistance to $\mathrm{H}_{2} \mathrm{O}_{2}$ over fermentation time of cells from culture effluent was tested as follows. Cells from frozen samples were twice subcultured in MRS inoculated at $1 \%(\mathrm{v} / \mathrm{v})$ and incubated anaerobically at $37^{\circ} \mathrm{C}$ for $24 \mathrm{~h}$. Aliquot of $1 \mathrm{ml}$ containing ca. $1.11 \pm 0.67 \times 10^{9} \mathrm{CFU}$ $\mathrm{ml}^{-1}$ was centrifuged at $6,000 \mathrm{~g}$ for $2 \mathrm{~min}$ and the pellet was suspended in $10 \mathrm{ml} 400 \mathrm{ppm} \mathrm{H}_{2} \mathrm{O}_{2}$ solution. After $1.5 \mathrm{~h}$ incubation at room temperature, the cell suspension was diluted in C-PBS and plated on MRS agar and incubated anaerobically at $37^{\circ} \mathrm{C}$ for $48 \mathrm{~h}$. Results were expressed as survival rate in percent before and after treatment. The test was performed in duplicate.

\section{Isolation of cells adapted to $\mathrm{H}_{2} \mathrm{O}_{2}$}

Frozen bead samples $(1 \mathrm{~g})$ collected at day 18 of continuous culture, were dissolved in $40 \mathrm{ml}$ 1\% EDTA, treated in a stomacher for $3 \mathrm{~min}$ and centrifuged at 6,000 $\mathrm{g}$ for $5 \mathrm{~min}$. Cell pellets were suspended in $10 \mathrm{ml} 40 \mathrm{ppm}$ $\mathrm{H}_{2} \mathrm{O}_{2}$ and incubated for $60 \mathrm{~min}$ at room temperature to recover fractions of populations adapted to $\mathrm{H}_{2} \mathrm{O}_{2}$ stress. $1 \mathrm{ml}$ of cell suspension was subsequently plated on MRS agar. Colonies visible within $48 \mathrm{~h}$ were twice subcultured anaerobically for $16 \mathrm{~h}$ in MRS broth at $37^{\circ} \mathrm{C}$ and frozen at $-80^{\circ} \mathrm{C}$ in MRS with $10 \%$ glycerol until further analyses.

\section{Characterization of $\mathrm{H}_{2} \mathrm{O}_{2}$ adapted isolates $\mathrm{H}_{2} \mathrm{O}_{2}$ resistance level of isolates}

Frozen samples of wild type and $\mathrm{H}_{2} \mathrm{O}_{2}$ adapted isolate cultures containing approximately $1.03 \pm 0.33 \times 10^{9}$ CFU ml ${ }^{-1}$ were thawed at room temperature. $1 \mathrm{ml}$ of sample was centrifuged at $6,000 \mathrm{~g}$ for $2 \mathrm{~min}$. The pellet was suspended in $10 \mathrm{ml} 200 \mathrm{ppm} \mathrm{H}_{2} \mathrm{O}_{2}$ solution. After $2 \mathrm{~h}$ incubation at room temperature cell suspensions were diluted in C-PBS and plated on MRS agar and incubated anaerobically at $37^{\circ} \mathrm{C}$ for $48 \mathrm{~h}$. Results were expressed as survival rate in percent before and after treatment. The test was performed in triplicate.

\section{Stability of $\mathrm{H}_{2} \mathrm{O}_{2}$ adapted phenotype}

Stability of $\mathrm{H}_{2} \mathrm{O}_{2}$ adapted phenotype of isolates was tested by subculturing cells without selective pressure in MRS at $37^{\circ} \mathrm{C}$ under anaerobic conditions for $24 \mathrm{~h}$. After each subculture, containing ca. $1.76 \pm 1.07 \times 10^{9} \mathrm{CFU}$ $\mathrm{ml}^{-1}$, resistance level to $\mathrm{H}_{2} \mathrm{O}_{2}$ of cells was tested using 400 ppm $\mathrm{H}_{2} \mathrm{O}_{2}$ solution as described above. The test was performed in duplicate.

\section{Growth in presence of oxygen in liquid shaking cultures}

Ability of cells to grow in presence of oxygen was tested according to Meile et al. [8] with some modifications. The headspace of $500 \mathrm{ml}$ serum flasks containing 400 $\mathrm{ml}$ MRS, after creating vacuum conditions was flushed with $\mathrm{N}_{2}$ or $\mathrm{CO}_{2}$ until normal atmosphere pressure was achieved; then 7.5 or $12.5 \%(\mathrm{v} / \mathrm{v})$ sterile oxygen were added. Afterwards, the medium was inoculated at $2 \%$ with an overnight culture of wild type or $\mathrm{H}_{2} \mathrm{O}_{2}$ resistant cells and the flasks were incubated at $37^{\circ} \mathrm{C}$ in a shaker at $160 \mathrm{rpm}$ (Kühner AG, Basel, Switzerland) for $24 \mathrm{~h}$. Samples were taken every $2 \mathrm{~h}$ during the first $12 \mathrm{~h}$ of the culture to measure optical density at $600 \mathrm{~nm}$. Two repetitions were carried out.

\section{Growth in reactor with and without $\mathrm{H}_{2} \mathrm{O}_{2}$}

Cells were grown in an 800-ml working volume reactor (1-1 reactor, Infors-HT) containing MRS inoculated at $5 \%$ with an overnight culture of wild type or $\mathrm{H}_{2} \mathrm{O}_{2}$ resistant cells. Temperature was controlled at $37^{\circ} \mathrm{C}$ and agitation set at $200 \mathrm{rpm}$. Anaerobic conditions were maintained by continuously sparging either $\mathrm{CO}_{2}$ or $\mathrm{N}_{2}$ in the medium, starting overnight prior inoculation. Cells were cultivated with and without addition of 42 ppm $\mathrm{H}_{2} \mathrm{O}_{2}$ in mid-exponential growth phase corresponding to an OD of 0.6. This $\mathrm{H}_{2} \mathrm{O}_{2}$ concentration of $42 \mathrm{ppm}$ causes a cessation in growth for at least $40 \mathrm{~min}$ of exponentially wild type cells of Bifidobacterium longum NCC2705 without a decrease in viable cell counts during this growth arrest [14]. Growth was monitored by measuring OD at $600 \mathrm{~nm}$. Samples for global transcriptional profiling were taken in mid-exponential growth phase after 3-3.5 h of culture at an OD of 0.70.8 in reactors sparged with $\mathrm{CO}_{2}$ and without $\mathrm{H}_{2} \mathrm{O}_{2}$. Aliquots of $2 \mathrm{ml}$ were centrifuged (4,000 g for $1 \mathrm{~min}$ ), supernatants discarded and cell pellets snap frozen in liquid nitrogen and stored at $-80^{\circ} \mathrm{C}$ until RNA-extraction. Fermentations were performed in triplicate.

\section{Microarray analysis \\ Microarray design and RNA extraction}

DNA based arrays, produced by Agilent Technologies http://www.agilent.com, were obtained by in situ synthesis of 60 mer oligonucleotides on glass slides [15]. For each gene, 3 to 6 different probes were randomly distributed on the array. Total RNA was extracted with the macaloïd method and purified as previously described [16].

\section{Array hybridization}

For each hybridization, cDNA was synthesized starting from $4 \mu \mathrm{g}$ of total RNA and subsequently labeled using the Array 900MPX Genisphere kit (Genisphere Inc., Hatfield, PE, USA), following the protocol provided by the supplier. Luciferase and kanamycin control mRNA (Promega, Zürich, Switzerland) at 1 and $10 \mathrm{ng}$, respectively, were mixed with total RNA before labeling to allow balancing of the two channels during scanning. After the hybridization procedure, array slides were scanned at $10 \mu \mathrm{m}$ using a Scanarray 4000 (Packard Biochip Technologies, Billerica, MA, USA). Laser power and photomultiplier tube gain were set in order to prevent saturation of any spot, except the probes corresponding to rRNA. 


\section{Array analysis}

Data extracted with Imagene 5.6 (Biodiscovery, El Segundo, CA, USA) were treated with homemade scripts in Python language http://www.python.org and a local installation of the ArrayPipe web server [17]. Probes showing a signal smaller than twice the standard deviation of the local background were considered without signal. Probes showing no signal or saturated signals in both channels were discarded from the analysis. Assuming an intensity-dependent variation in dye signal, (limma) loess global normalization was applied on signal ratios. To calculate average gene expression values, data from 3 biological replicates were combined as follows. Within each hybridization data set, gene fold changes were calculated from the median of the corresponding probes values. The expression value of a gene was retained if a signal was detected in at least $50 \%$ of its probes. Genes were considered to be differentially expressed if their $\log _{2}$-transformed signal ratios were higher than 1.5 or smaller than -1.5. Statistical analysis of the 3 biological array replicates of the hybridization between wild type and $\mathrm{H}_{2} \mathrm{O}_{2}$ resistant cells were performed using the statistical software $\mathrm{R}$ version 2.6.1 [18]. Bayes statistics for differential expression [19] was used to rank genes in order of evidence for differential expression. The data have been deposited in NCBI's Gene Expression Omnibus and are accessible through GEO Series accession number GSE16039. TMHMM-prediction server version 2.0 was used to identify transmembrane domains of predicted proteins [20].

\section{Results}

\section{Continuous culture monitoring}

The concentration of $\mathrm{H}_{2} \mathrm{O}_{2}$ in the continuous culture with immobilized cells of B. longum NCC2705 was increased stepwise to $130 \mathrm{ppm}$ in order to select for cells resistant to oxidative stress (Figure 1). At day 2, optical density of the fermented effluent reached 8.4, corresponding to $1.26 \times 10^{9} \mathrm{CFU} \mathrm{ml}^{-1}$. Subsequently, OD decreased and increased after each increase in $\mathrm{H}_{2} \mathrm{O}_{2}$ concentration. Viable cells in effluent samples before changing the level of $\mathrm{H}_{2} \mathrm{O}_{2}$ concentration ranged from $6.31 \times 10^{8}$ to $2.00 \times 10^{9} \mathrm{CFU} \mathrm{ml}^{-1}$ until day 8 (Figure 1). Following $\mathrm{H}_{2} \mathrm{O}_{2}$ concentration increase to $130 \mathrm{ppm}$ at day 9, the OD decreased to 0 . To enrich potentially hydrogen peroxide resistant survivors after this harsh treatment, the addition of $\mathrm{H}_{2} \mathrm{O}_{2}$ was stopped for 2 days and the flow rate of the medium was decreased to 0.9 $\mathrm{ml} \mathrm{min}{ }^{-1}$, resulting in a new phase of growth with an increase of OD to 3.2 at day 11 in effluent samples, corresponding to $6.31 \times 10^{5} \mathrm{CFU} \mathrm{mm^{-1 }}$. Concentration of $\mathrm{H}_{2} \mathrm{O}_{2}$ was then set again at $100 \mathrm{ppm}$ and OD decreased again to 0 with viable cell counts in the effluent

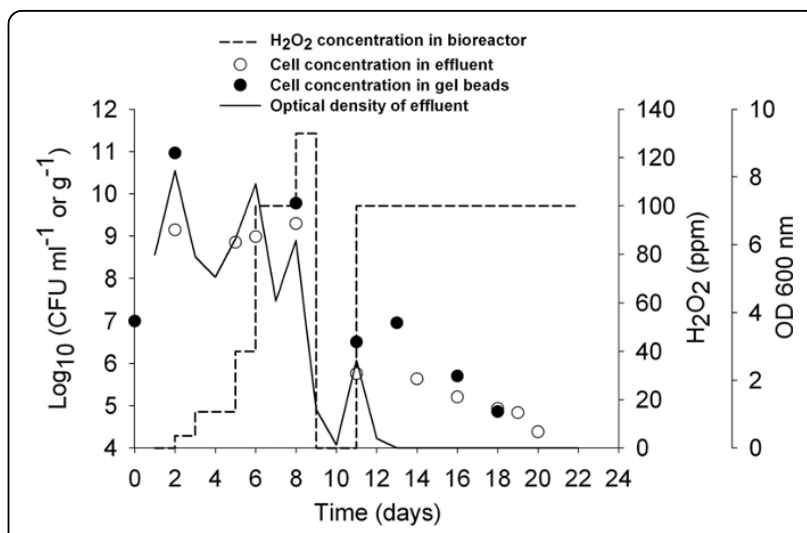

Figure 1 Continuous culture monitoring. The figure shows the optical density of fermented effluent, $\mathrm{H}_{\mathbf{2}} \mathrm{O}_{2}$ concentration in bioreactor, viable cells counts in gel beads and in the effluent during continuous culture with immobilized cells of $\boldsymbol{B}$. longum NCC2705 and $\mathrm{H}_{\mathbf{2}} \mathrm{O}_{\mathbf{2}}$ selective pressure.

gradually decreasing from $3.98 \times 10^{5}$ at day 14 to $2.51 \times$ $10^{4} \mathrm{CFU} \mathrm{ml} \mathrm{m}^{-1}$ at day 20 (Figure 1). Cell counts in gel beads were generally 1 to 2 log higher than in effluent samples, except at the end of culture where both population reached similar levels (Figure 1).

$\mathrm{H}_{2} \mathrm{O}_{2}$ resistance of free cells in the culture effluent remained stable during the first 8 days with a survival rate of $0.00010 \pm 0.00004 \%$ (Figure 2). At day 14 and 18 the survival rate was 760 and 16 folds higher than for day 1 , respectively (Figure 2 ).

\section{Selection of resistant cells and stability of $\mathrm{H}_{2} \mathrm{O}_{2}$ resistance phenotype}

Because a large fraction of cell biomass of the system was in the bead matrix (ca. $10^{11} \mathrm{CFU} \mathrm{g}^{-1}$ beads after

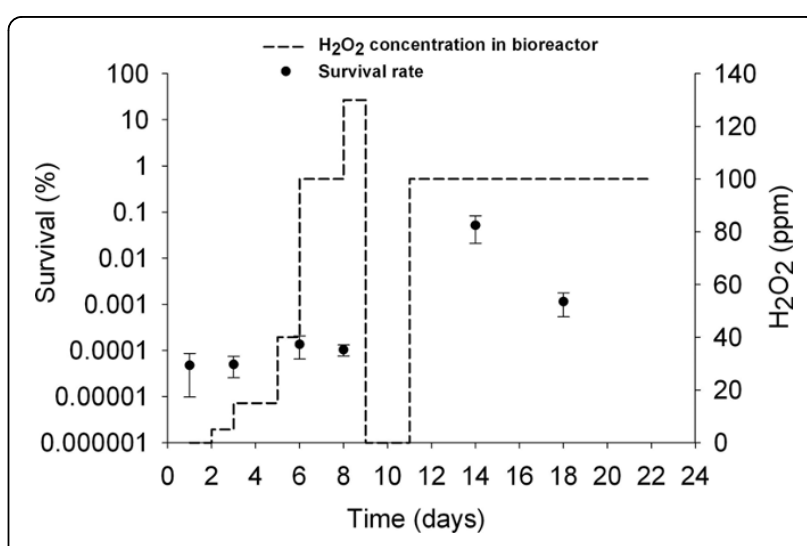

Figure 2 Resistance of cells collected from fermented effluent to $\mathrm{H}_{2} \mathrm{O}_{2}$. Resistance of cells from fermented effluent to $\mathrm{H}_{2} \mathrm{O}_{2}$ as a function of fermentation time was assessed after incubation in 400 ppm $\mathrm{H}_{2} \mathrm{O}_{2}$ solution for $1.5 \mathrm{~h}$ and expressed in \% survival. Applied concentrations of $\mathrm{H}_{2} \mathrm{O}_{2}$ in the bioreactor are also indicated. Data are means of two replicates \pm standard deviation. 
colonization) at the beginning of the fermentation, a higher number of adapted cells was expected in the gel beads, which were physically retained in the reactor, than in effluent at the end of culture. Cells from gel beads collected at day $18\left(6.31 \times 10^{4} \mathrm{CFU} \mathrm{g}^{-1}\right)$ were subjected to an isolation step, and tested for their resistance to $\mathrm{H}_{2} \mathrm{O}_{2}$. Two colonies, namely HPR1 and HPR2, were detected after this isolation step. Tolerance to $\mathrm{H}_{2} \mathrm{O}_{2}$ of cells from these two isolates was 20 -and 30 -folds higher, respectively, than that of wild type cells (Figure 3 ). A stability test was performed with these two isolates using a hydrogen peroxide concentration of $400 \mathrm{ppm}$ and incubation time of 2 hours. After three successive subcultures, HPR1 cells exhibited similar resistance level to wild type cells, whereas HPR2 maintained its phenotype over at least 11 subsequent cultures (Figure 4). The survival tests showed large variations depending on the testing day; however a repetition of this test showed similar trends (data not shown).

\section{Growth in presence of oxygen in liquid shaking cultures}

HPR2 and wild type cells grew at similar rate of $0.47 \pm$ $0.03 \mathrm{~h}^{-1}$ and reached the same optical density of $5.22 \pm$ 0.36 after $24 \mathrm{~h}$ culture in presence of $100 \%$ nitrogen or carbon dioxide in the headspace (Figures 5 and 6). When the atmosphere of the headspace was composed of 7.5 and $92.5 \%$ of oxygen and nitrogen, respectively, HPR2 cells grew at a lower rate of $0.09 \pm 0.00 \mathrm{~h}^{-1}$ and reached an OD of $0.60 \pm 0.02$ after $24 \mathrm{~h}$ culture while growth of wild type cells was negligible with a growth rate of $0.01 \pm 0.00 \mathrm{~h}^{-1}$ and a final OD of $0.15 \pm 0.02$ (Figure 5). Using a headspace of 12.5 and $87.5 \%$ of oxygen and carbon dioxide, respectively, the growth rate during the first $11.5 \mathrm{~h}$ was $0.12 \pm 0.01$ and $0.04 \pm 0.01$

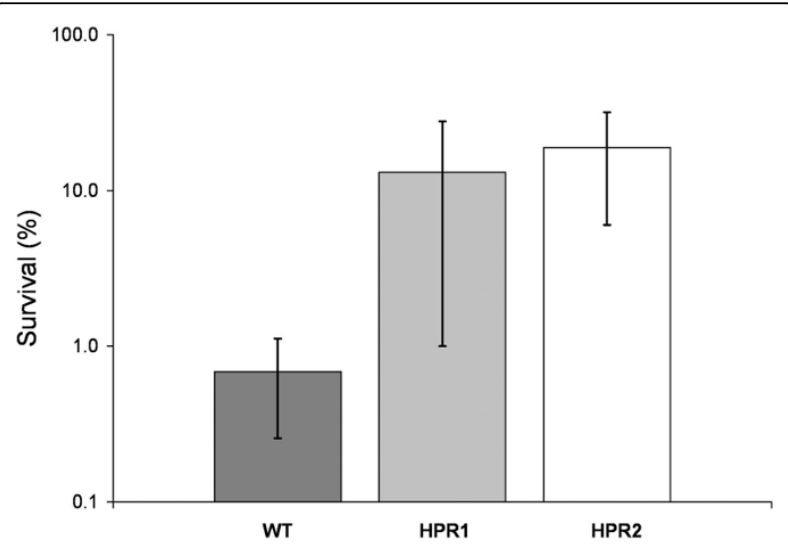

Figure 3 Resistance level of isolates HPR1 and HPR2 and of wild type (WT) $B$. longum $\mathrm{NCC} 2705$ to $\mathrm{H}_{2} \mathrm{O}_{2}$. Resistance was assessed after incubation of cells in 200 ppm $\mathrm{H}_{2} \mathrm{O}_{2}$ solution for $2 \mathrm{~h}$ and expressed in \% survival. Data are means of three replicates \pm standard deviation.

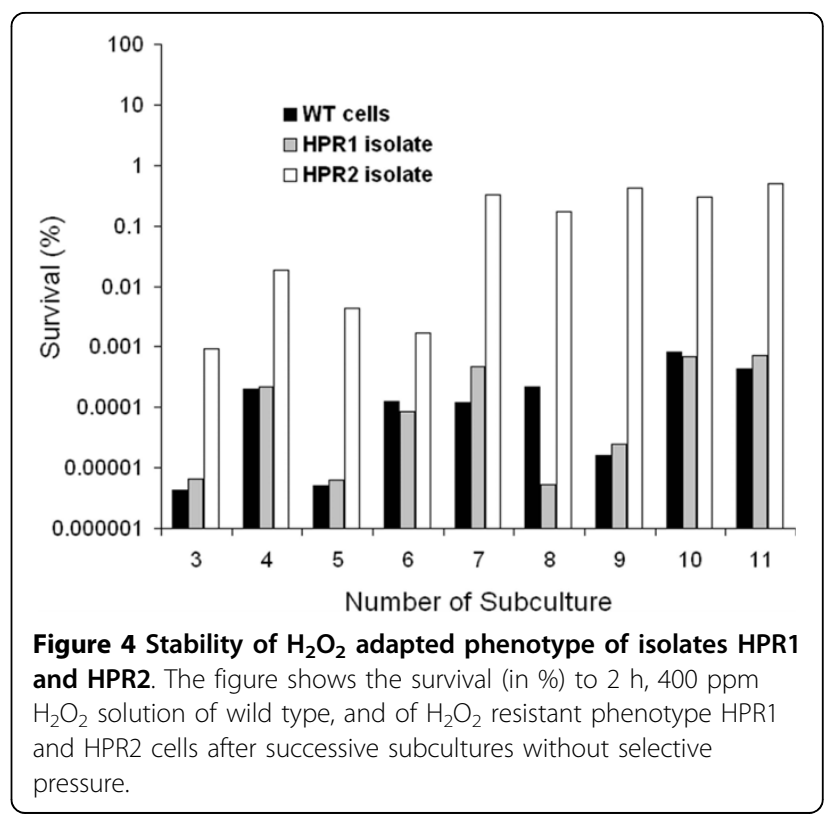

$\mathrm{h}^{-1}$ for HPR2 and wild type cells, respectively (Figure 6). From 11.5 to $24 \mathrm{~h}$ of culture, both strains grew at similar rate of $0.15 \pm 0.01 \mathrm{~h}^{-1}$ and reached a final OD of $1.44 \pm 0.25$ and $0.81 \pm 0.19$ for HPR2 and wild type cells, respectively (Figure 6).

\section{Growth in presence of $\mathrm{H}_{2} \mathrm{O}_{2}$ in reactors}

Both wild type and HPR2 cells recovered rapidly and in a similar manner after addition of $\mathrm{H}_{2} \mathrm{O}_{2}$ in medium sparged with carbon dioxide, and reached the same OD of $6.06 \pm 0.60$ than non treated cells after $24 \mathrm{~h}$ of culture (Figure 7). In presence of nitrogen, HPR2 strain started to recover earlier (1.63 vs. $2.51 \mathrm{~h}$ after addition of hydrogen peroxide) and grew at a higher rate $(0.24 \pm$ 0.02 vs. $0.13 \pm 0.03 \mathrm{~h}^{-1}$ ) than wild type cells after $\mathrm{H}_{2} \mathrm{O}_{2}$ addition, reaching an optical density of $1.41 \pm 0.02$ and $0.70 \pm 0.18$, respectively, after $8 \mathrm{~h}$ culture (Figure 8 ). Growth of HPR2 and wild type cells, treated or not with $\mathrm{H}_{2} \mathrm{O}_{2}$, were negatively affected by sparging nitrogen compared to carbon dioxide in the medium (Figures 7 and 8).

\section{Genome-wide transcription analysis}

Transcriptome analysis of exponentially growing cells without selective pressure showed that in HPR2 compared to wild type cells, the genes BL1404 and BL0931 were overexpressed. BL1404 was over-expressed with an average $\log _{2}$ ratio of 3.1 (2.3-3.8, 95\% confidence interval) and $1.5(1.6-1.7,95 \% \mathrm{CI})$ for $B L 0931$. The start codon of BL0931 gene is 45 nucleotide downstream of BL0932 stop codon, a gene encoding an ABC-transporter ATP-binding protein. Both genes are predicted to be on the same operon, a prediction which is supported by 


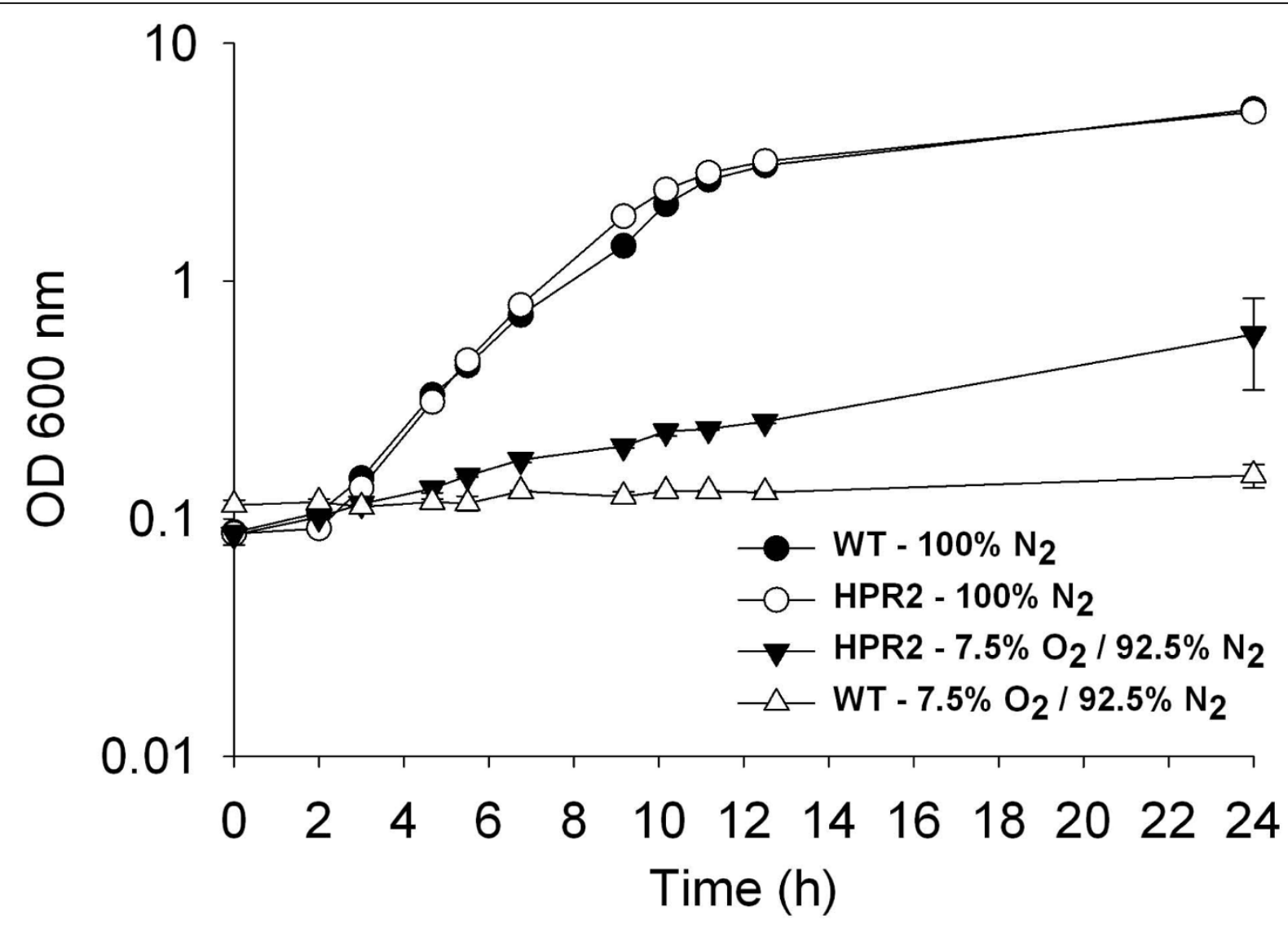

Figure 5 Growth of HPR2 and wild type B. longum NCC2705 in presence of $100 \% \mathrm{~N}_{2}$ and of $7.5 \% \mathrm{O}_{2}-\mathbf{- 9 2 . 5 \%} \mathrm{N}_{\mathbf{2}}$. Cells were grown in liquid shaking cultures. Growth was monitored using optical density at $600 \mathrm{~nm}$. Data are means of two replicates \pm standard deviation.
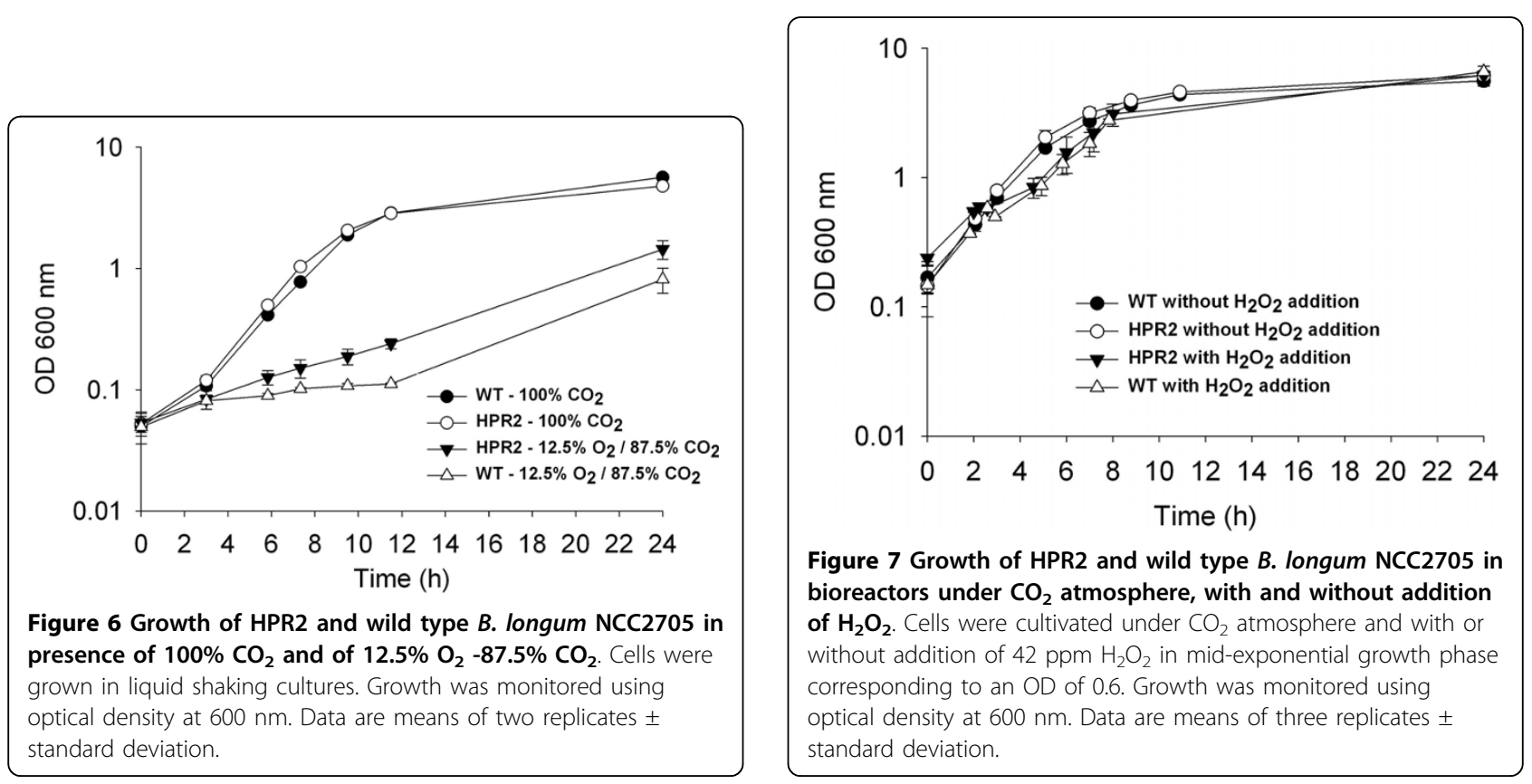


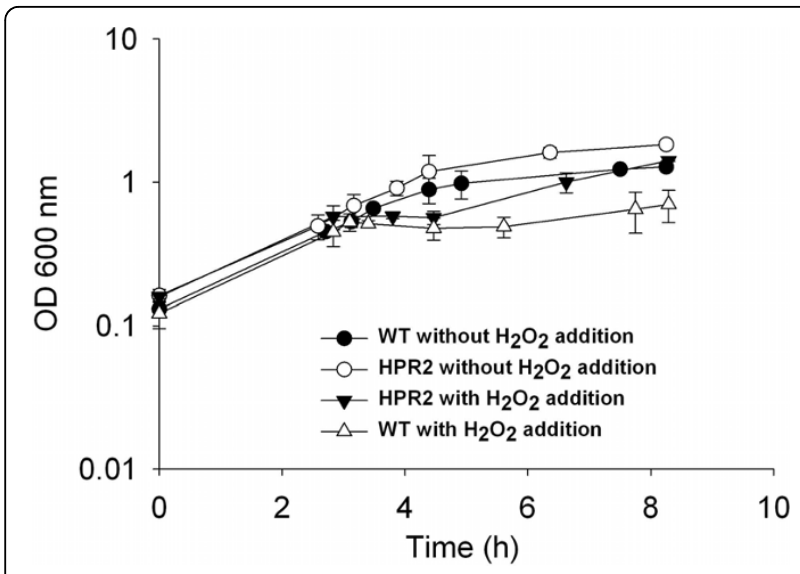

Figure 8 Growth of HPR2 and wild type $B$. longum NCC2705 in bioreactors under $\mathrm{N}_{2}$ atmosphere, with and without addition of $\mathrm{H}_{2} \mathrm{O}_{2}$. Cells were cultivated under $\mathrm{N}_{2}$ atmosphere and with or without addition of $42 \mathrm{ppm} \mathrm{H}_{2} \mathrm{O}_{2}$ in mid-exponential growth phase corresponding to an OD of 0.6. Growth was monitored using optical density at $600 \mathrm{~nm}$. Data are means of three replicates \pm standard deviation.

the similar average gene expression profile displayed by the $B L 0932$ gene $(1.4 ; 0.9-1.9,95 \% \mathrm{CI})$. All remaining genes had $\log _{2}$ transformed ratios lower than 1.5 and non significant $\mathrm{p}$-values.

\section{Discussion}

In this study, we tested the suitability of continuous culture under increasing selective pressure combined with immobilized cell technology for the selection of hydrogen peroxide adapted bifidobacteria cells. Continuous system allows cultivation of cells over an unlimited number of generations under strictly controlled conditions. In addition continuously cultured cells may undergo a number of consecutive mutational events, each contributing to improve adaptation of cells to their environment [21,22]. Evolutionary engineering approaches using chemostats or repeated batch cultures, combined with constant or gradually increasing selective pressure have been successfully exploited to increase resistance of industrially relevant microorganisms, mainly yeast cells, to environmental stresses [23-25].

A very high cell concentration was reached in beads $\left(10^{11} \mathrm{CFU} \mathrm{g}{ }^{-1}\right.$ beads) leading to a high total population, including immobilized and free cells, of $10^{13} \mathrm{CFU}$ per litre of reactor similar to that reported by Doleyres et al. [26] with immobilized B. longum cells in gellan gum beads during continuous culture operated at a dilution rate of $0.5 \mathrm{~h}^{-1}$. As a comparison, batch cultures with free cells of $B$. longum NCC2705 generally reach $10^{9}$ $\mathrm{CFU} \mathrm{m} \mathrm{m}^{-1}$, corresponding to $10^{12} \mathrm{CFU}$ per litre of reactor at the end of the culture (data not shown). This high cell density could favor the occurrence of mutations since the rate of appearance of mutational events is proportional to the amount of biomass in the culture [27].

The continuous culture gradually adapted to increasing $\mathrm{H}_{2} \mathrm{O}_{2}$ concentrations, as shown by the culture oscillating OD. However, the B. longum population tested in the effluent reached an upper limit of its adaptive capabilities at day 9 with $\mathrm{H}_{2} \mathrm{O}_{2}$ concentration of 130 ppm. Immobilization of the cells in gel matrix has prevented full wash-out, which would have very likely occurred with a free cell system. Hence after stopping the stress, it was possible to re-grow the cells that survived this high $\mathrm{H}_{2} \mathrm{O}_{2}$ concentration. After this enrichment step

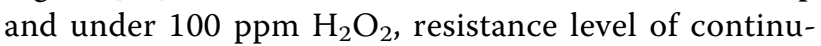
ously produced cells was higher than those tested at the beginning of the fermentation but decreased to an intermediate level at day 18 . Heterogeneity in the immobilized and free populations which can exhibit different resistance level and/or adaptive mechanisms to the selective pressure, as discussed below for cells isolated from gel beads, could explain this change in resistance to $\mathrm{H}_{2} \mathrm{O}_{2}$ with fermentation time and using the same conditions. Çakar et al. [25] reported a heterogeneous resistance levels to cobalt for single cells within an evolved population of Saccharomyces cerevisiae subjected to continuous increasing levels of cobalt stress.

HPR1 and HPR2, isolated from gel beads at day 18, showed a 20-and 30-fold higher resistance to $\mathrm{H}_{2} \mathrm{O}_{2}$ than wild type cells, respectively. Two different mechanisms can be proposed to explain the adaptive response of these two isolates in regard to the stability of their phenotype. HPR1 isolate lost rapidly its hydrogen peroxide adapted phenotype which could be the result of a transient adaptation caused by the stressing conditions encountered in gel beads and not necessarily by $\mathrm{H}_{2} \mathrm{O}_{2}$ selective pressure. Indeed, it was already reported that immobilized $B$. longum cells, continuously cultivated without specific selective pressure adapt to $\mathrm{H}_{2} \mathrm{O}_{2}$ stress [28]. This phenotype was reversible after subculturing, and could be related to a non specific stress adaptation caused by diffusional limitations of both substrates and inhibitory products in the gel beads [29]. Resistance phenotype of HPR2 isolate to $\mathrm{H}_{2} \mathrm{O}_{2}$ was much more stable (at least over 70 generations) than that of HPR1 indicating a probable stable mutation. To our knowledge, this is the first description of a mutant strain of bifidobacteria resistant to $\mathrm{H}_{2} \mathrm{O}_{2}$. HPR2 cells were then further characterized.

HPR2 could tolerate higher $\mathrm{O}_{2}$ level than wild type cells of $B$. longum NCC2705 and the moderately oxygen-tolerant $B$. thermophilum RBL67 as reported by von Ah et al. [29]. The ability of HPR2 isolate to grow in presence of oxygen can be associated with its $\mathrm{H}_{2} \mathrm{O}_{2}$ adapted phenotype. Indeed, accumulation of $\mathrm{H}_{2} \mathrm{O}_{2}$ during culture of sensitive bifidobacteria in presence of 
oxygen is generally considered as the primary reason for growth inhibition $[7,30,31]$. Additionally, HPR2 and wild type cells seem to tolerate more $\mathrm{O}_{2}$ in presence of $\mathrm{CO}_{2}$ than with $\mathrm{N}_{2}$ in the headspace of the culture. This result is different from that of Kawasaki et al. [30] who reported that colony development of different Bifidobacterium species under an atmosphere composed of 5 and $95 \% \mathrm{O}_{2}$ and $\mathrm{N}_{2}$, respectively, was not improved by addition of $\mathrm{CO}_{2}$. This difference can be explained by the methodology and strains used in our studies. The better growth of HPR2 and wild type cells observed in reactor with medium sparged with $\mathrm{CO}_{2}$ instead of $\mathrm{N}_{2}$ are in agreement with others studies reporting the essential role of $\mathrm{CO}_{2}$, even at low level, to stimulate growth of bifidobacteria [30,32]. Presence of residual dissolved $\mathrm{CO}_{2}$ in MRS medium for liquid shaking culture, can also explain the lack of difference between growth of HPR2 and wild type cells in presence of $100 \% \mathrm{~N}_{2}$ or $\mathrm{CO}_{2}$ in the headspace, in contrast to cultures in reactor where these gases were directly sparged into the medium.

A known mechanism influencing sensitivity of Bifidobacteria to oxygen is the type of NADH oxidase activity. In $\mathrm{O}_{2}$ sensitive species, NADH oxidase exhibits $\mathrm{H}_{2} \mathrm{O}_{2}$ forming activity while $\mathrm{H}_{2} \mathrm{O}$ is produced in microaerophilic species [6,31]. B. longum NCC2705 possess a gene (BL1266), which codes for a putative NADH oxidase with an active site for the four electron reduction of $\mathrm{O}_{2}$ to $\mathrm{H}_{2} \mathrm{O}$ and could therefore be implied in the detoxification of $\mathrm{H}_{2} \mathrm{O}_{2}$ [14]. However, BL1266 is not differentially expressed in HPR2 compared to wild type cells. Constitutive overproduction of oxidative stress related proteins can also protect cells to $\mathrm{H}_{2} \mathrm{O}_{2}$ as observed in a mutant strain of Bacteroides fragilis resistant to $\mathrm{H}_{2} \mathrm{O}_{2}$ [33]. In HPR2 another mechanism seems to be involved in the resistance to $\mathrm{H}_{2} \mathrm{O}_{2}$. Two genes, BL1404 and BL0931, were constitutively overexpressed in HPR2 compared to wild type cells. These two genes were not differentially expressed in wild type cells exposed to $\mathrm{H}_{2} \mathrm{O}_{2}$ [14]. BLAST search [34] showed that BL1404, which is annotated as hypothetical protein [35], is highly homologous, 99\% on nucleotide level, to the integral membrane protein BLD_0271 from B. longum DJ010A. The BLAST search could not identify homologous genes in other bacteria, indicating that BL1404 encodes a protein specific to bifidobacteria. The BL1404 protein possesses three predicted transmembrane domains and 2 outer and 2 inner domains. BL0931 is annotated as possible ABCtype transport system involved in lipoprotein release. The functional predictions of the two differentially expressed genes do not suggest any mechanistic explanation for the resistance phenotype of the HPR2 isolate. For this purpose further experiments are required. Transcriptional profiling in the presence of $\mathrm{H}_{2} \mathrm{O}_{2}$ might be more informative for characterization of the resistance phenotype. Moreover, transcriptional profiling analysis is known to be useless for mutations that do not impact gene expression. Therefore, for future experiments, whole genome sequencing using next-generation sequencing technologies will most likely provide better mechanistic insight.

\section{Conclusions}

Our study showed that continuous culture with cell immobilization is a valid approach for selecting cells adapted to hydrogen peroxide. Cell immobilization allowed maintaining high cell numbers in the reactor, even when high selective pressure was applied. This enabled controlled application of stress at high levels on the culture over a long time. Additionally, preliminary characterization of HPR2 revealed the constitutive induction of two genes associated with the cell membrane. However, their function needs further characterization. Elucidation of $\mathrm{H}_{2} \mathrm{O}_{2}$ resistance mechanisms in HPR2 could be helpful to improve resistance of bifidobacteria to oxidative stress.

\section{Acknowledgements}

This study was carried out thanks to the financial support of the Commission of Technology and Innovation of Switzerland (CTI-Project Nr. 75272 LSPP-LS) and Nestle (Switzerland).

\section{Author details}

'Laboratory of Food Biotechnology, Institute of Food Science and Nutrition, Schmelzbergstrasse 7, ETH-Zurich, 8092 Zürich, Switzerland. ${ }^{2}$ Nestlé Research Center, Vers-chez-les-Blanc, 1000 Lausanne 26, Switzerland.

\section{Authors' contributions}

VM carried out the experimental part and contributed to draft the manuscript. FG participated to the design of the experiments and drafted the manuscript. DM performed all microarray experiments. BB and ER provided essential inputs for the microarray analysis and together with $\mathrm{CL}$, FA and FG, conceived the initial approaches. LM participated to the analysis of the genomic data and to draft the manuscript. CL acted as overall supervisor and corresponding author of the work. All authors have read and approved the final version of the manuscript.

\section{Competing interests}

Nestec S.A partly supported this project and applied for a patent for the hydrogen peroxide resistant strain.

\section{Received: 4 May 2010 Accepted: 27 July 2010 Published: 27 July 2010}

\section{References}

1. FAO/WHO: Joint FAO/WHO Working Group Report on Drafting Guidelines for the Evaluation of Probiotics in Food: April 30 and May 1, London, Ontario, Canada 2002.

2. Lacroix C, Yidirim S: Fermentation technologies for the production of probiotics with high viability and functionality. Curr Opin Biotechnol 2007, 18:176-183.

3. Vasijevic T, Shah NP: Probiotics - From Metchnikoff to bioactives. Int Dairy J 2008, 18:714-728.

4. Simpson PJ, Ross RP, Fitzgerald GF, Stanton C: Bifidobacterium psychraerophilum sp. nov. and Aeriscardovia aeriphila gen. nov., sp. nov., isolated from a porcine caecum. Int J Syst Evol Microbiol 2004, 54:401-406.

5. Biavati B, Mattarelli P: The family Bifidobacteriaceae. The Prokaryotes NewYork: SpringerFalkow S, Rosenberg E, Schleifer KH, Stackebrandt E, Dworkin M, 3 2001, 322-382. 
6. Kawasaki S, Mimura T, Satoh T, Takeda K, Niimura Y: Response of the microaerophilic Bifidobacterium species, B. boum and B. thermophilum, to oxygen. Appl Environ Microbiol 2006, 72:6854-6858.

7. Talwalkar A, Kailasapathy $\mathrm{K}$ : The role of oxygen in the viability of probiotic bacteria with reference to $L$. acidophilus and Bifidobacterium spp. Curr Issues Intest Microbiol 2004, 5:1-8.

8. Meile L, Ludwig W, Rueger U, Gut C, Kaufmann P, Dasen G, Wenger S, Teuber M: Bifidobacterium lactis sp. nov, a moderately oxygen tolerant species isolated from fermented milk. Syst Appl Microbiol 1997, 20:57-64

9. Shiuann YS, Chen MC, Liao CC: Bifidobacteria strains with acid, bile salt and oxygen tolerance and their culture method. US Patent 5,711,977 1998.

10. Narendranath NV, Thomas KC, Ingledew WM: Urea hydrogen peroxide reduces the numbers of lactobacilli, nourishes yeast, and leaves no residues in the ethanol fermentation. Appl Environ Microbiol 2000, 66:4187-4192.

11. Doleyres $Y$, Lacroix $C$ : Technologies with free and immobilised cells for probiotic bifidobacteria production and protection. Int Dairy J 2005, 15:973-988.

12. De Man JC, Rogosa M, Sharpe EM: A medium for the cultivation of lactobacilli. J Appl Bacteriol 1960, 23:130-135.

13. Cinquin C, Le Blay G, Fliss I, Lacroix C: Immobilization of infant fecal microbiota and utilization in an in vitro colonic fermentation model. Microb Ecol 2004, 48:128-138.

14. Klijn A: Physiological and molecular characterization of stress responses in Bifidobacterium longum NCC2705. PhD thesis University College Cork 2005.

15. Wolber PK, Collins PJ, Lucas AB, De Witte A, Shannon KW: The Agilent in situ-synthesized microarray platform. Methods Enzymol 2006, 410:28-57.

16. Parche S, Beleut M, Rezzonico E, Jacobs D, Arigoni F, Titgemeyer F, Jankovic I: Lactose-over-glucose preference in Bifidobacterium longum NCC2705: $g / c P$, encoding a glucose transporter, is subject to lactose repression. J Bacteriol 2006, 188:1260-1265.

17. Hokamp K, Roche FM, Acab M, Rousseau ME, Kuo B, Goode D, Aeschliman D, Bryan J, Babiuk LA, Hancock RE, others: ArrayPipe: a flexible processing pipeline for microarray data. Nucleic Acids Res 2004, 32 W457-459.

18. Team RDC: R: A language and environment for statistical computing. Vienna, Austria: R Foundation for Statistical Computing 2007.

19. Smyth GK: Linear models and empirical bayes methods for assessing differential expression in microarray experiments. Stat Appl Genet Mol Biol 2004, 3, Article3.

20. Krogh A, Larsson B, von Heijne G, Sonnhammer ELL: Predicting transmembrane protein topology with a hidden Markov model: Application to complete genomes. J Mol Biol 2001, 305:567-580.

21. Butler PR, Brown M, Oliver SG: Improvement of antibiotic titers from Streptomyces bacteria by interactive continuous selection. Biotechnol Bioeng 1996, 49:185-196.

22. Novick A, Szilard L: Experiments with the chemostat on spontaneous mutations of bacteria. PNAS 1950, 36:708-719.

23. Sauer U: Evolutionary engineering of industrially important microbial phenotypes. Adv Biochem Eng Biotechnol 2001, 73:129-169.

24. Çakar ZP, Seker UOS, Tamerler C, Sonderegger M, Sauer U: Evolutionary engineering of multiple-stress resistant Saccharomyces cerevisiae. FEMS Yeast Res 2005, 5:569-578.

25. Çakar ZP, Alkim C, Turanli B, Tokamn N, Akman S, Sarikaya M, Tamerler C, Benbadis L, FranÇois JM: Isolation of cobalt hyper-resistant mutants of Saccharomyces cerevisiae by in vivo evolutionary engineering approach. $J$ Biotechnol 2009, 143:130-138.

26. Doleyres $Y$, Paquin C, LeRoy M, Lacroix C: Bifidobacterium longum ATCC 15707 cell production during free-and immobilized-cell cultures in MRSwhey permeate medium. Appl Microbiol Biotechnol 2002, 60:168-73.

27. Lane PG, Oliver SG, Butler PR: Analysis of a continuous-culture technique for the selection of mutants tolerant to extreme environmental stress. Biotechnol Bioeng 1999, 65:397-406.

28. Doleyres Y, Fliss I, Lacroix C: Increased stress tolerance of Bifidobacterium longum and Lactococcus lactis produced during continuous mixed-strain immobilized-cell fermentation. J Appl Microbiol 2004, 97:527-539.

29. von Ah U, Mozzetti V, Lacroix C, Kheadr EE, Fliss I, Meile L: Classification of a moderately oxygen-tolerant isolate from baby faeces as Bifidobacterium thermophilum. BMC Microbiol 2007, 7.
30. Kawasaki S, Nagasaku M, Mimura T, Katashima H, ljyuin S, Satoh T, Niimura Y: Effect of $\mathrm{CO} 2$ on colony development by Bifidobacterium species. Appl Environ Microbiol 2007, 73:7796-7798.

31. Kawasaki S, Satoh T, Todoroki M, Niimura $Y$ : b-type dihydroorotate dehydrogenase is purified as a $\mathrm{H}_{2} \mathrm{O}_{2}$-forming $\mathrm{NADH}$ oxidase from Bifidobacterium bifidum. Appl Environ Microbiol 2009, 75:629-636.

32. Ninomiya K, Matsuda K, Kawahata T, Kanaya T, Kohno M, Katakura Y, Asada M, Shioya S: Effect of $\mathrm{CO}_{2}$ concentration on the growth and exopolysaccharide production of Bifidobacterium longum cultivated under anaerobic conditions. J Biosci Bioeng 2009, 107:535-537.

33. Rocha ER, Smith CJ: Characterization of a peroxide-resistant mutant of the anaerobic bacterium Bacteroides fragilis. J Bacteriol 1998, 180:5906-5912.

34. Zhang Z, Schwartz S, Wagner L, Miller W: A greedy algorithm for aligning DNA sequences. J Comput Biol 2000, 7:203-214.

35. Schell MA, Karmirantzou M, Snel B, Vilanova D, Berger B, Pessi G, Zwahlen MC, Desiere F, Bork P, Delley M, others: The genome sequence of Bifidobacterium longum reflects its adaptation to the human gastrointestinal tract. PNAS 2002, 99:14422-14427.

doi:10.1186/1475-2859-9-60

Cite this article as: Mozzetti et al: New method for selection of hydrogen peroxide adapted bifidobacteria cells using continuous culture and immobilized cell technology. Microbial Cell Factories 2010 9:60.

\section{Submit your next manuscript to BioMed Central and take full advantage of:}

- Convenient online submission

- Thorough peer review

- No space constraints or color figure charges

- Immediate publication on acceptance

- Inclusion in PubMed, CAS, Scopus and Google Scholar

- Research which is freely available for redistribution 